\title{
DEFORMABILITY AND CRACK RESISTANCE OF AIRFIELD SLABS
}

\author{
${ }^{1}$ Surianinov M.G., Doctor of Science, Professor, \\ sng@ogasa.org.ua, ORCID: 0000-0003-2592-5221 \\ ${ }^{1}$ Neutov S.P., PhD, Assistant Professor, \\ neutov.stepan@gmail.com, ORCID: 0000-0002-0132-124X \\ ${ }^{1}$ Korneeva I.B., PhD, Assistant Professor, \\ korneevairinaborisovna@gmail.com, ORCID: 0000-0002-0104-6938 \\ ${ }^{1}$ Odesa State Academy of Civil Engineering and Architecture \\ Didrikhsona str., 4, Odesa, 65029, Ukraine
}

\begin{abstract}
The results of experimental studies of deformability and crack resistance of models of airfield slabs made of reinforced concrete and steel fiber concrete are presented. Two series of plates were tested - three models of reinforced concrete and three models with steel fiber added to the concrete mixture in amount of $1 \%$ of the total volume of the product. The load was applied in small steps, the instrument readings were recorded twice at each step, and the crack opening width was measured starting from the moment of the first crack formation. Dial gauges and deflectometers were used as measuring instruments. According to the normative documents acting in Ukraine, one of two possible loading schemes was considered - with the loading by the concentrated force applied on the cantilever part of a plate. The plate models were tested on a specially made stand which consisted of four supporting struts connected in pairs by beams. The airfield slab was supported by the beams. The load was applied along the width of the plate in steps -0.05 of the destructive load, along two concentrated vertical strips. Each degree of load ended with a five-minute dwell time, at the beginning and end of which readings were taken on the measuring instruments. The deformations at the same levels were measured with dial gauges. The process of crack formation was observed with a Brinell tube in the places of the greatest crack opening.

It follows from the obtained results that the process of cracking in the fiber concrete slab begins at higher loads than in the reinforced concrete slab. The final and initial crack opening widths of all cracks in the fiber concrete slab are significantly lower than in the reinforced concrete slab. The deformations in steel-fiber concrete slabs during the application of load in the cantilever part, both for compressed and stretched fibers are higher than in reinforced concrete slabs. At the initial stages of load application in the cantilevered part of the slabs, the deflections increase in a linear relationship. The curves get non-linear character for airfield slabs made of reinforced concrete when the load reaches the level of $10 \div 25 \mathrm{kN}$, for steel-fiber-concrete slabs $-15 \div 30 \mathrm{kN}$. In reinforced concrete slabs, the non-linearity starts a little earlier and is expressed more clearly. Experimental studies show that dispersed reinforcement of airfield slabs with steel fiber leads to their higher crack resistance.

Keywords: reinforced concrete, fiber concrete, airfield slab, deformability, crack resistance, experimental studies.

Introduction. Airfield slab pavements have many advantages over monolithic pavements: a fairly simple construction technology; no labor-intensive operation of laying concrete; high quality of slabs due to their production in factory conditions; possibility of year-round construction and commissioning the pavement immediately after its laying. The disadvantages of prefabricated coatings are high metal consumption and a very large number of joints, which worsen the evenness of coverage. Pre-stressed reinforced concrete slabs of PAG type are used for the construction of precast airfield pavements. In recent years, new concretes with very high strength and deformative properties have appeared, but the question of ensuring durability and crack resistance of reinforced concrete structures under conditions of natural or technological influence of high positive or negative temperatures still remains relevant. One of the effective ways to solve this problem is dispersed reinforcement of structures.
\end{abstract}


Among the many factors that determine the efficiency and durability of a structure, deformability and crack resistance are no less important than bearing capacity. Their comprehensive study is the most informative in experimental research. This paper describes the results of the experiment, which was carried out in the scientific laboratory of the Department of Structural Mechanics of the Odessa State Academy of Civil Engineering and Architecture - the deformability and crack resistance of models of airfield slab PAG-18.

Recent studies analysis. The deformability and crack resistance of reinforced concrete structures have been studied in a great number of works, and many of them deal with slabs. However, the studies related to airfield or road slabs are clearly insufficient, and the publications related to steel-fiber-reinforced slabs are practically absent.

The range of airfield slab design schemes recommended by the regulatory documents of different countries is quite wide and ambiguous. Historically, the first proposed scheme represents the airfield slab as a slab on an elastic base. And in this direction there are the greatest number of publications. The general concept of calculation of road and airfield slabs was proposed by B.N. Zhemochkin and A.P. Sinitsyn [1]. Later their ideas were developed by many authors, among which we should mention Belarusian scientists [2, 3].

The crack resistance of slabs remains a subject of close attention of scientists. Thus, in [4] the results of the research allowing to estimate the degree of influence of pre-organized cracks on the character of cracking and the process of deformation of multi-hollow floor slabs under short-term load action are presented. The results of experimental and theoretical studies of the stiffness and crack resistance of reinforced concrete multiple-core floor slabs reinforced in the tensile zone by carbon fiber reinforcement glued to the outer surface of the concrete are presented in [5]. The crack resistance of the composite slab, which is the floor of the first floor of the building, is analyzed in [6] at the stages of erection, loading and unloading, construction and operation. The influence of fiber type and fiber length on crack resistance, strength and porous structure of the concrete slab is investigated by the authors of [7]. It is noted that the fiber reinforced concrete shows better frost resistance.

The increase in terrorist attacks and natural disasters has led to increased demands on the impact resistance of concrete structures, and, as a consequence, to an increase in the number of works in this direction. In the article [8], the impact resistance of double-sided concrete slabs was studied by conducting multiple impact tests. Two types of reinforcement fibers were used - steel fibers with bent ends and straight steel fibers. It was found that steel fiber concrete shows increased resistance to impact loads.

Note two more works $[9,10]$ devoted to the research of crack resistance of dispersed reinforced slabs, the results of which indicate a significant improvement in the deformation properties of slabs with their dispersed reinforcement.

The purpose of this work is to experimentally investigate the deformability and crack resistance of models of airfield slabs made of reinforced concrete and steel-fiber concrete.

Materials and research methodology. Two series of slabs were made - three models of reinforced concrete and three models with steel fiber added to the concrete mixture $1 \%$ of the total volume of the product. The load was applied in small steps to study the deformation process of the slab in detail. At each step, instrument readings were recorded twice, and the crack opening width was measured starting from the moment of formation of the first crack. Strain gauges, dial gauges, deflectometers and Brinell tube were used as measuring instruments [11].

Research results. The dimensions of the tested road slabs were $1375 \times 825 \times 60 \mathrm{~mm}$. The specimens were reinforced with a spatial framework consisting of two meshes (Fig. 1). For reinforced concrete and steel-fiber-concrete slabs, reinforcement of type Vr-1 with a diameter of $5 \mathrm{~mm}$ was used. 


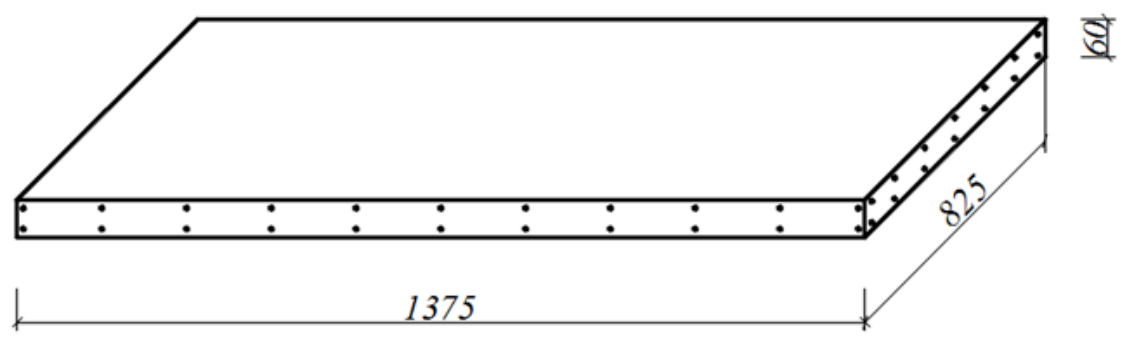

Fig. 1. General view of the slab

According to the regulatory documents in force in Ukraine $[12,13]$, airfield slabs (as well as road slabs) are calculated by two loading schemes - when the load is a concentrated force applied in the middle of the span, and when the load is a concentrated force applied on the console. Here we consider the cantilever loading scheme (Fig. 2).

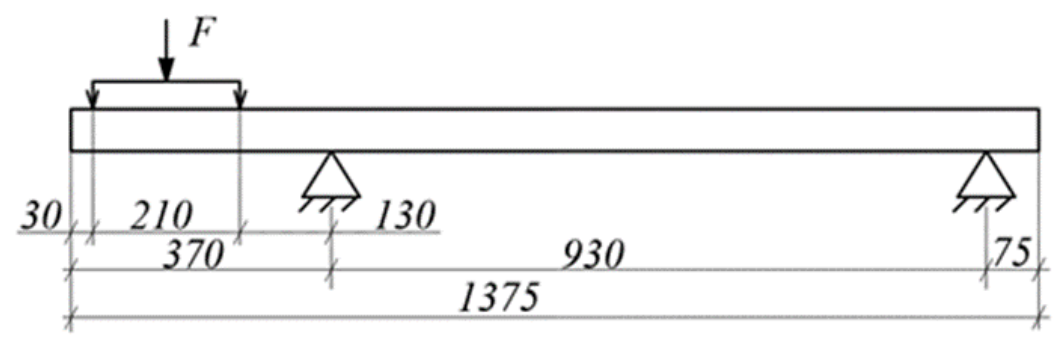

Fig. 2. Cantilever loading scheme

The slab models were tested on the stand, which consisted of four support legs connected in pairs by beams. The airfield slab rested on the beams. The load was applied along the width of the plate in steps -0.05 of the destructive load, along two concentrated vertical strips. Each degree of load ended with a five-minute dwell time, at the beginning and end of which readings were taken on the measuring instruments. All tests were performed using a $100 \mathrm{kN}$ jack and a five-ton dynamometer No. 917. The jack's operating principle is that its lower surface presses on a two-level cross-beam system, and through it, the load is distributed to the plate (Fig. 3).

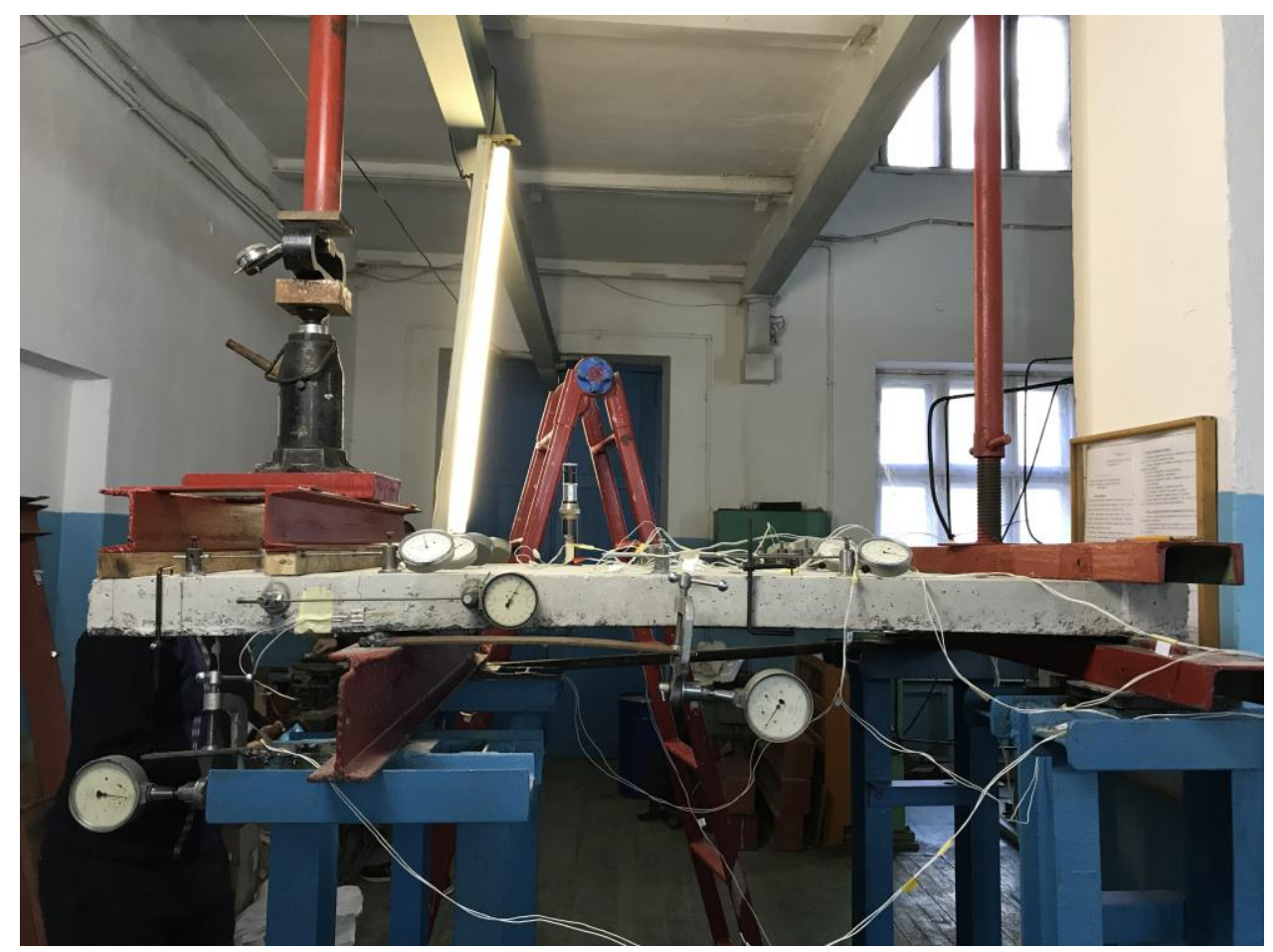

Fig. 3. Test stand 
During the test, the load applied to the plate specimens was recorded, as well as the deflections and deformations. The deformations at the same levels were measured using dial gauges with a division value of $0.01 \mathrm{~mm}$ and a base of $24 \mathrm{~cm}$ - in the cantilever part of the plate, $36 \mathrm{~cm}-$ in the span. The process of cracking on the surfaces of the plates was observed with a Brinell tube in the places of greatest crack opening. The division value of the Brinell tube was $0.1 \mathrm{~mm}$.

In accordance with the adopted loading scheme, two rows of indicators were installed on the top surface of the slab (Fig. 4). The first group of four indicators (2, 3, 4 and 5) was installed on the cantilever loading section of the model, and the second group (7, 8, 9 and 10) - in the upper span of the slab. Gauges 1, 6 were mounted on the side faces in the support area of the cantilever section. A pair of indicators 11,12 recorded the deformations of the compressed zone in the span section of the slab.

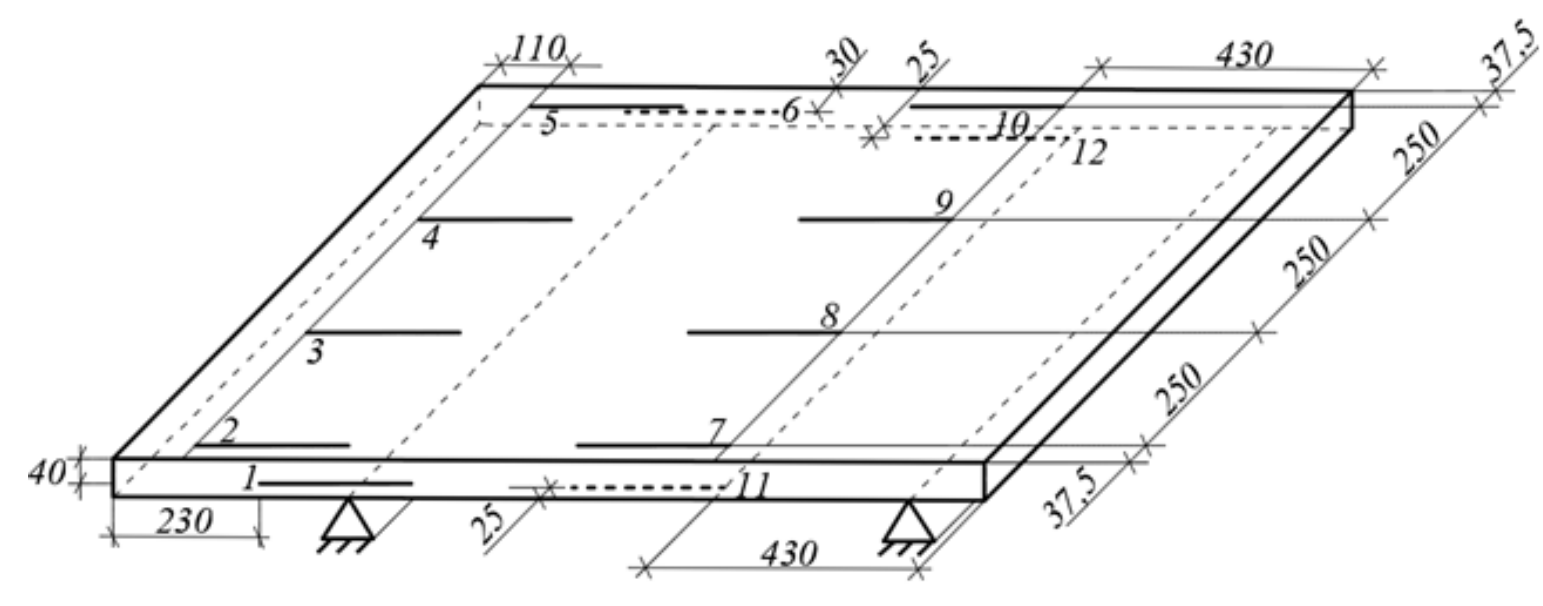

Fig. 4. Location of gauges

The main results of the tests are shown in Table 1.

Table 1 - Research results

\begin{tabular}{|l|c|c|c|c|}
\hline \multirow{2}{*}{ Slab model } & \multicolumn{2}{|c|}{ Start cracking } & \multirow{2}{*}{ Bearing capacity, $\mathrm{kN}$} & $\begin{array}{c}\text { Limit moment } \\
\text { at failure, } \mathrm{kNm}\end{array}$ \\
\cline { 2 - 5 } & Load, $\mathrm{kN}$ & Moment, $\mathrm{kNm}$ & & 4.34 \\
\hline Reinforced concrete & 10.84 & 2.55 & 18.46 & 5.71 \\
\hline Fiber concrete & 14.00 & 3.29 & 24.30 & \\
\hline
\end{tabular}

Based on the readings of the gauges, plots of the relative strain from the load in the tensile zone of the cantilevered part of the reinforced concrete (Fig. 5) and fiber concrete (Fig. 6) slab have been plotted. 


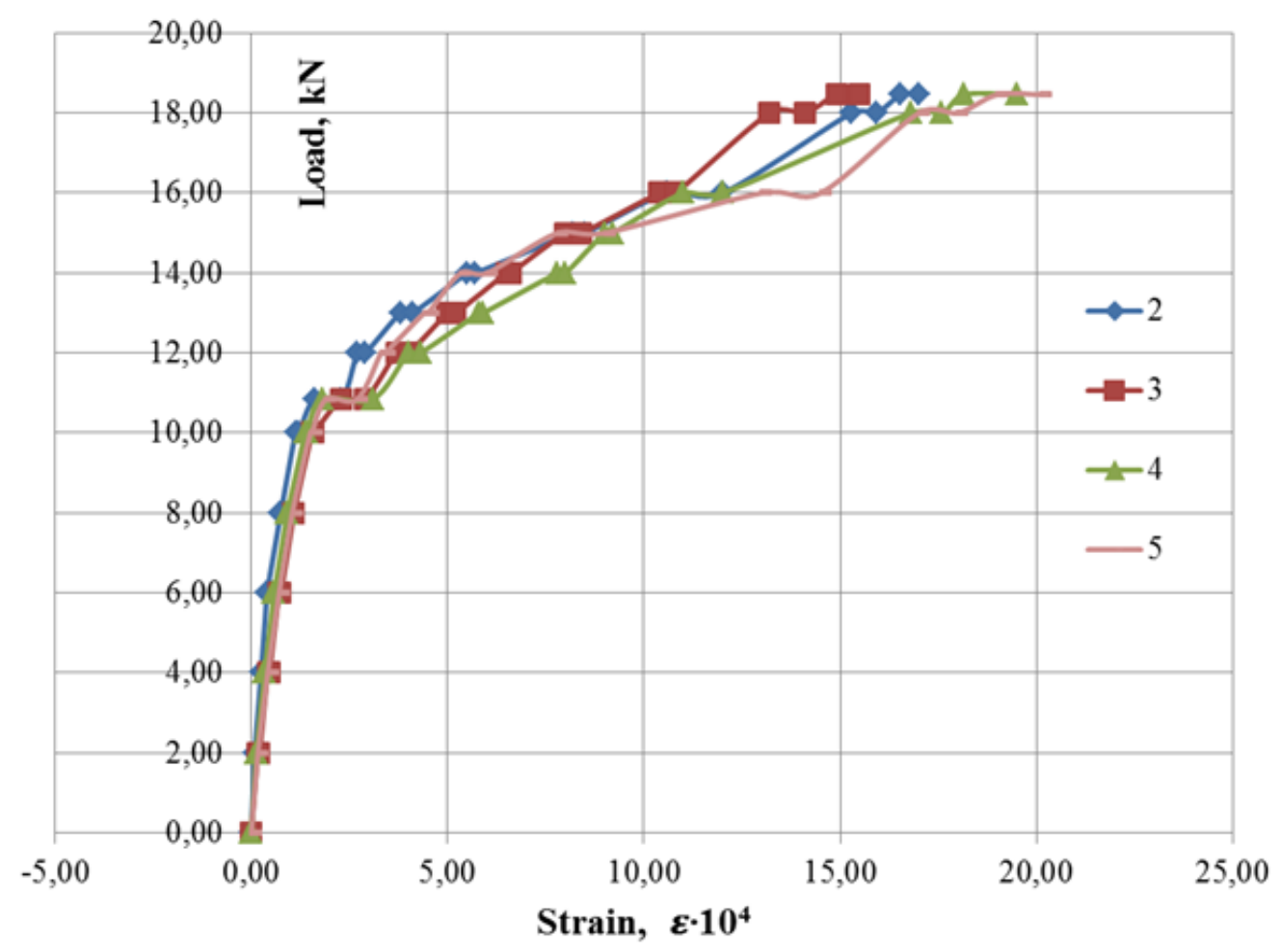

Fig. 5. Strain in the tensile zone on the console of a reinforced concrete slab

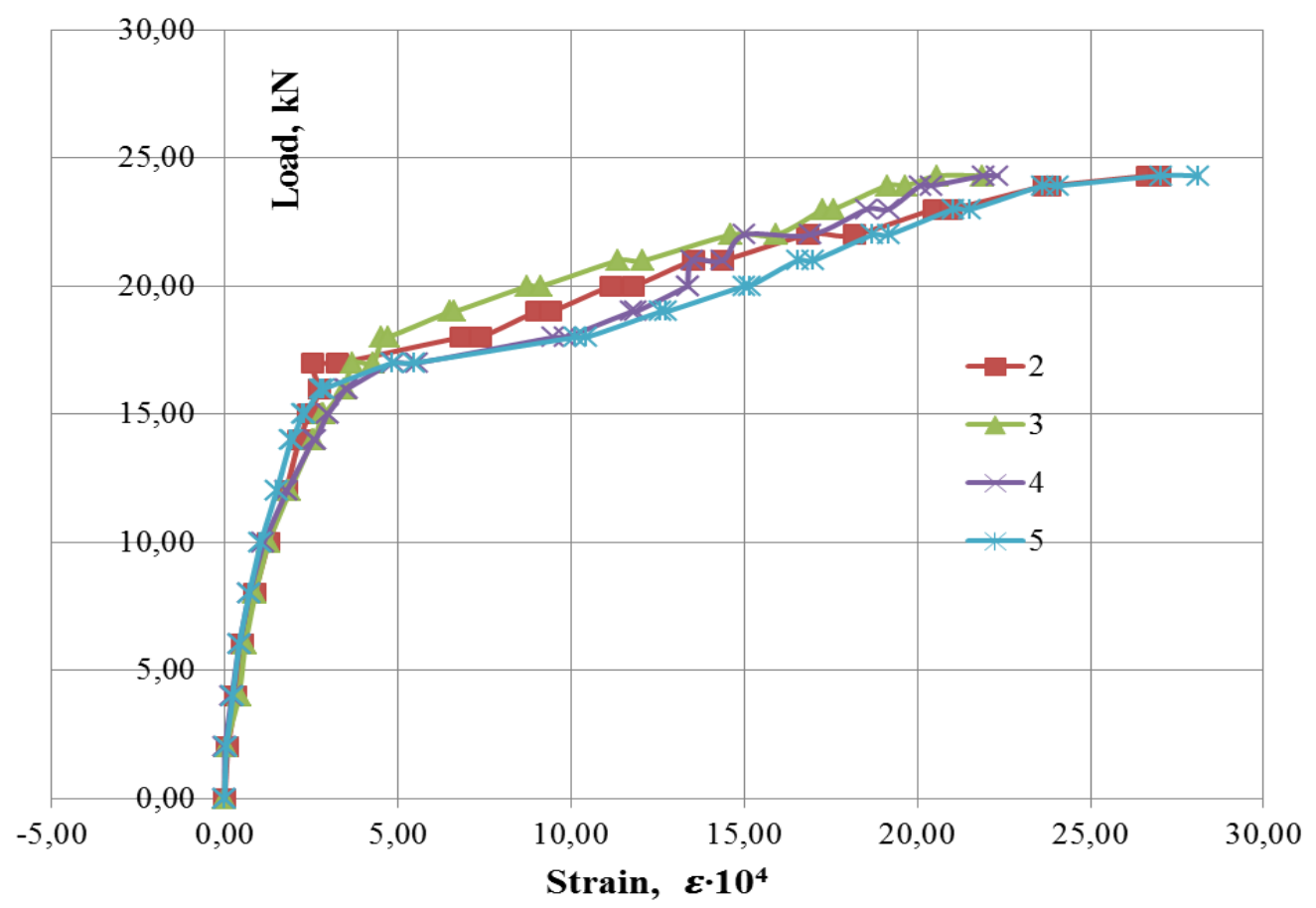

Fig. 6. Deformations in the tensile zone on the console of the fiber concrete slab

Plots of the dependence of the relative strain on the load in the tensile zone of the span of reinforced concrete and fiber concrete slab are shown in Fig. 7 and Fig. 8, respectively.

On the basis of the measurements we have built a number of other graphs (which we do not quote here due to the limited size of the paper) - the relative strain according to indicator readings in the supporting sections on the side planes of the slab; the relative strain according to indicator readings in the span on the bottom slab surface; relative strain according to load cell readings; relative strain according to indicator readings and load cells in the stretched zone; relative strain according to indicator readings and load cells in the compressed zone. 


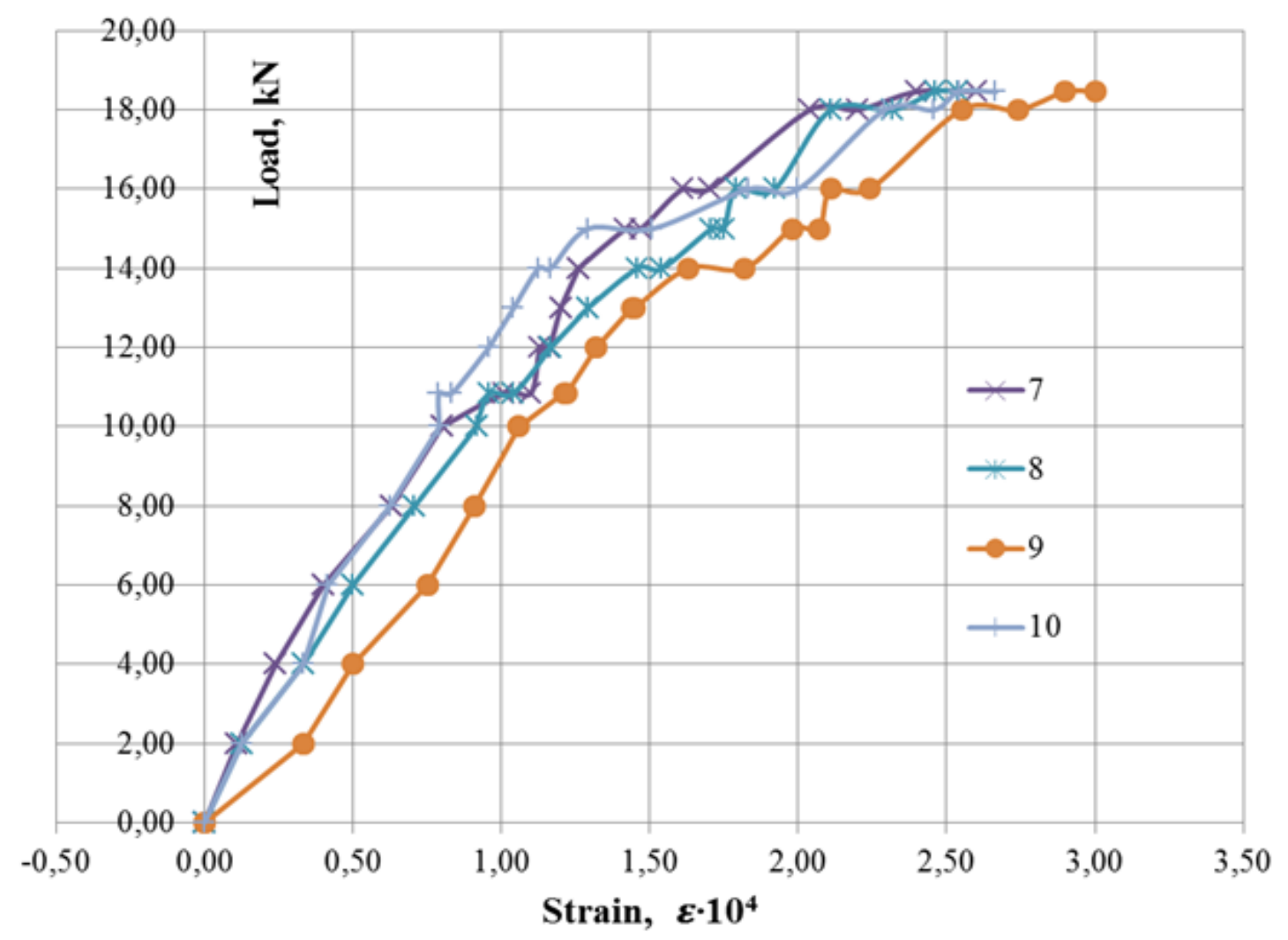

Fig. 7. Deformations in the tensile zone of the span of a reinforced concrete slab

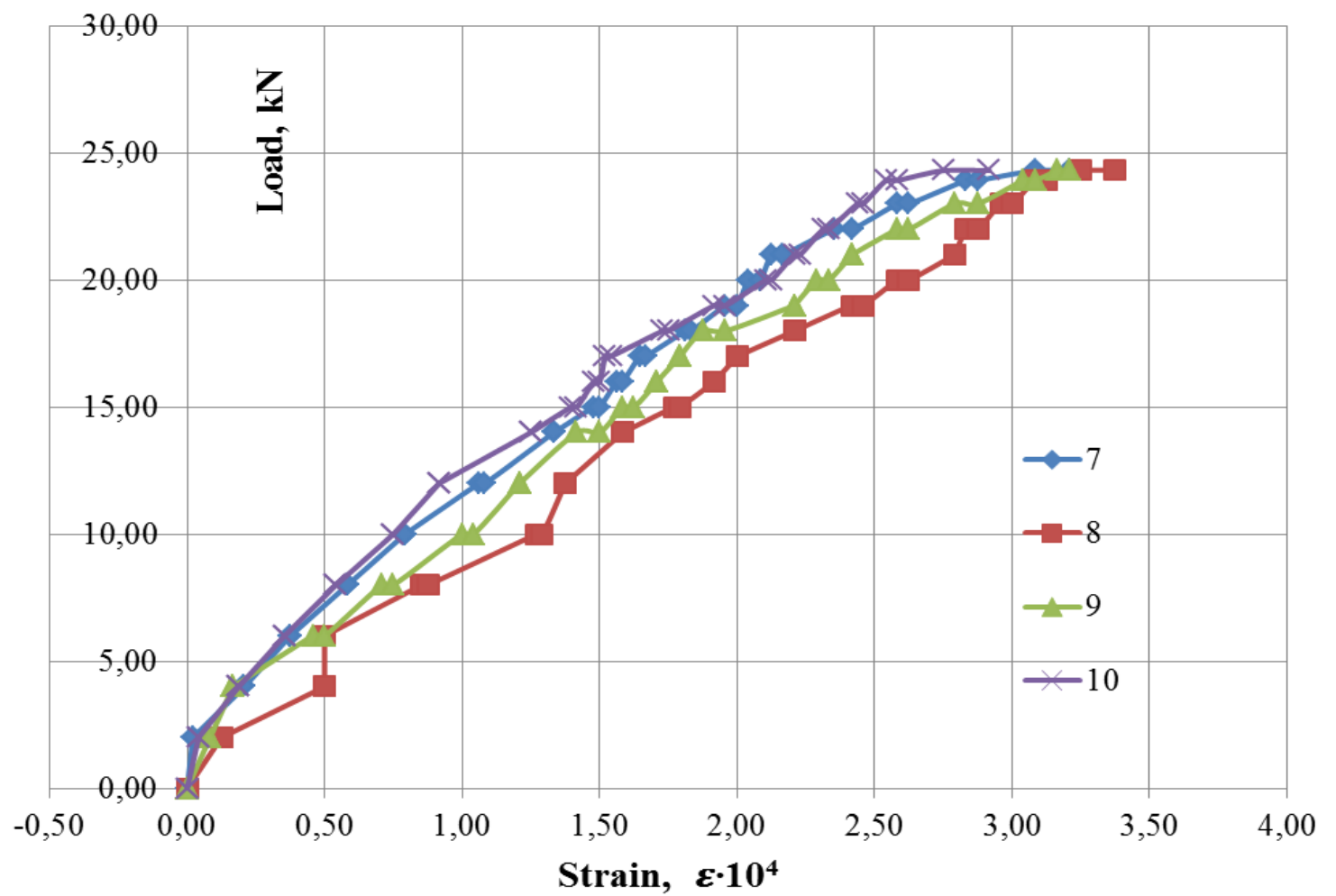

Fig. 8. Deformations in the tensile zone of the span of the fiber concrete slab

Table 2 shows the sequence of crack formation in reinforced concrete and fiber concrete slabs with increasing load, and Table 3 shows the crack opening width. 
BUILDING STRUCTURES

Table 2 - Sequence of crack formation in the slabs with increasing load

\begin{tabular}{|c|c|c|c|c|c|c|c|}
\hline \multicolumn{2}{|c|}{ № loading steps } & \multicolumn{2}{c|}{ Load, $\mathrm{kN}$} & \multicolumn{2}{c|}{ № of crack } & \multicolumn{2}{c|}{$\begin{array}{c}\text { Minimum height of the } \\
\text { compressed zone, mm }\end{array}$} \\
\hline RC slab & SFC slab & RC slab & SFC slab & RC slab & SFC slab & RC slab & SFC slab \\
\hline 0 & 0 & 0.00 & 0.00 & & & & \\
\hline 1 & 1 & 2.00 & 2.00 & & & & \\
\hline 2 & 2 & 4.00 & 4.00 & & & & \\
\hline 3 & 3 & 6.00 & 6.00 & & & & \\
\hline 4 & 4 & 8.00 & 8.00 & & & & \\
\hline 5 & 5 & 10.00 & 10.00 & & & & \\
\hline 6 & 6 & 10.84 & 12.00 & 1 & & 17 & \\
\hline 7 & 7 & 12.00 & 14.00 & & 1 & & \\
\hline 8 & 8 & 13.00 & 15.00 & & & & \\
\hline 9 & 9 & 14.00 & 16.00 & & & & \\
\hline 10 & 10 & 15.00 & 16.99 & & 2 & & \\
\hline 11 & 11 & 16.00 & 17.99 & & & & \\
\hline 12 & 12 & 17.99 & 18.99 & 2 & & 8 & \\
\hline 13 & 13 & 18.46 & 19.99 & 3 & & 5 & \\
\hline & 14 & & 20.99 & & & & \\
\hline & 15 & & 21.99 & & 3 & & \\
\hline & 16 & & 22.99 & & & & \\
\hline & 17 & & 23.92 & & & & \\
\hline & 18 & & 24.30 & & & & \\
\hline
\end{tabular}

Table 3 - Crack opening width with increasing load

\begin{tabular}{|c|c|c|c|c|c|c|c|}
\hline \multicolumn{2}{|c|}{ № of crack } & \multicolumn{2}{c|}{ Bending moment, kNm } & \multicolumn{2}{|c|}{ Initial opening width, mm } & \multicolumn{2}{c|}{$\begin{array}{c}\text { Final opening width, } \\
\mathrm{mm}\end{array}$} \\
\hline RC slab & SFC slab & RC slab & SFC slab & RC slab & SFC slab & RC slab & SFC slab \\
\hline 1 & 1 & 2.55 & 3.29 & 0.1 & 0.05 & 1 & 0.5 \\
\hline 2 & 2 & 4.23 & 3.99 & 0.1 & 0.05 & 0.25 & 0.2 \\
\hline 3 & 3 & 4.34 & 5.17 & 0.1 & 0.05 & 0.5 & 0.3 \\
\hline
\end{tabular}

Using the data from the two deflectometers, we plotted the deflections versus load for the reinforced concrete (Fig. 9) and fiber concrete (Fig. 10) slabs, which have the same character as the deformation plots. Before the appearance of the first crack, the deflection of reinforced concrete slab is $9.2 \%$ for reinforced concrete slab and $38.1 \%$ for fiber concrete slab from that recorded at the end of tests.

Conclusions. As follows from the above results, the cracking process in the fiber concrete slab begins at higher loads than in the reinforced concrete slab. The final and initial width of all cracks in the fiber concrete slab is significantly lower than in the reinforced concrete slab.

The deformations in steel fiber concrete slabs when the load is applied in the cantilevered part, both for compressed and stretched fibers, are higher than in reinforced concrete slabs.

According to the given results, it can be seen that at the initial stages of load application in the span of the plates, the deflections increase linearly. The curves get non-linear for airfield slabs of reinforced concrete, when the load reaches the level of $10 \div 25 \mathrm{kN}$, for steel fiber concrete slabs $-15 \div 30$ $\mathrm{kN}$. In reinforced concrete slabs the non-linearity starts a little earlier and is more clearly expressed.

Thus, the experimental studies indicate that dispersed reinforcement of airfield slabs with steel fiber leads to their higher crack resistance. 


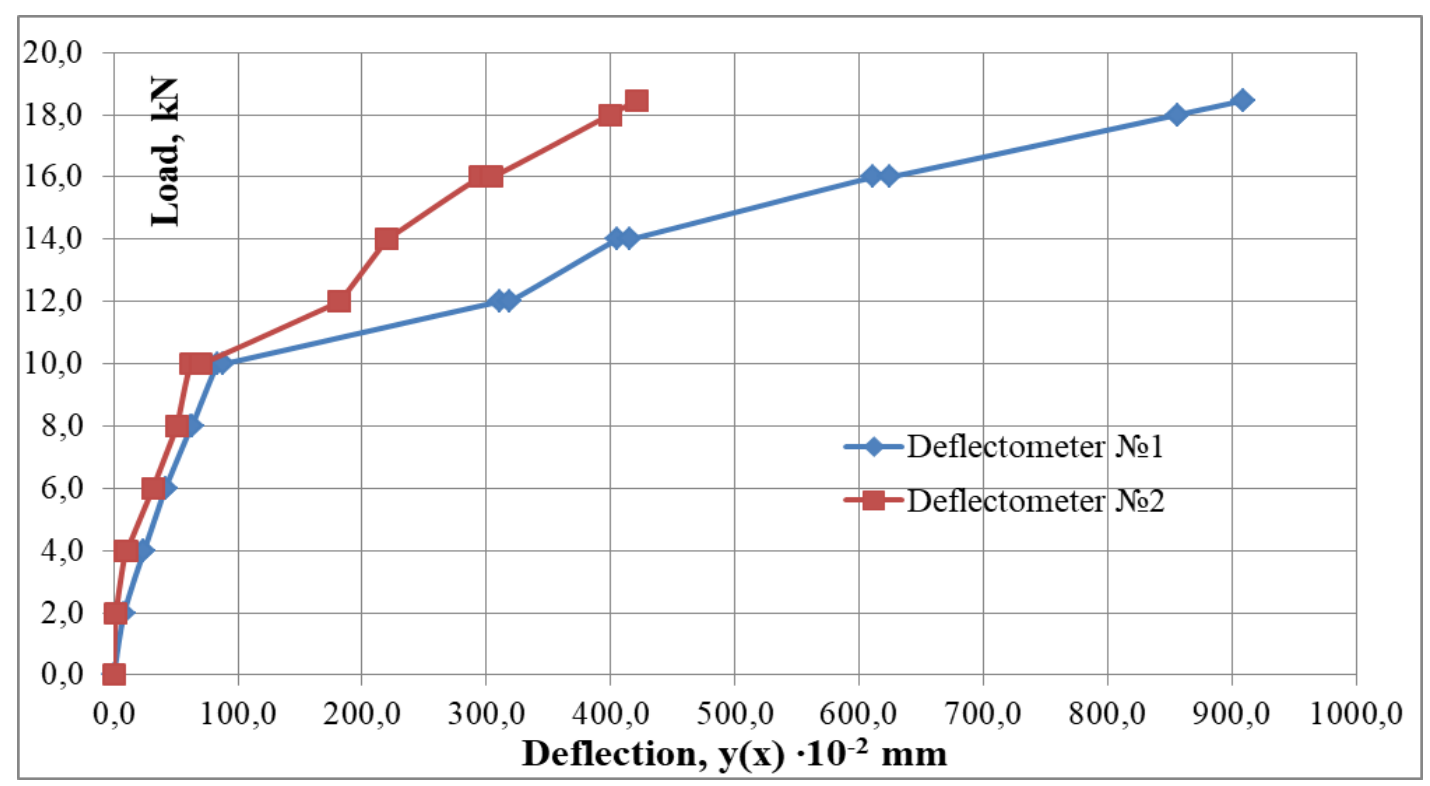

Fig. 9. Deflections in a reinforced concrete slab

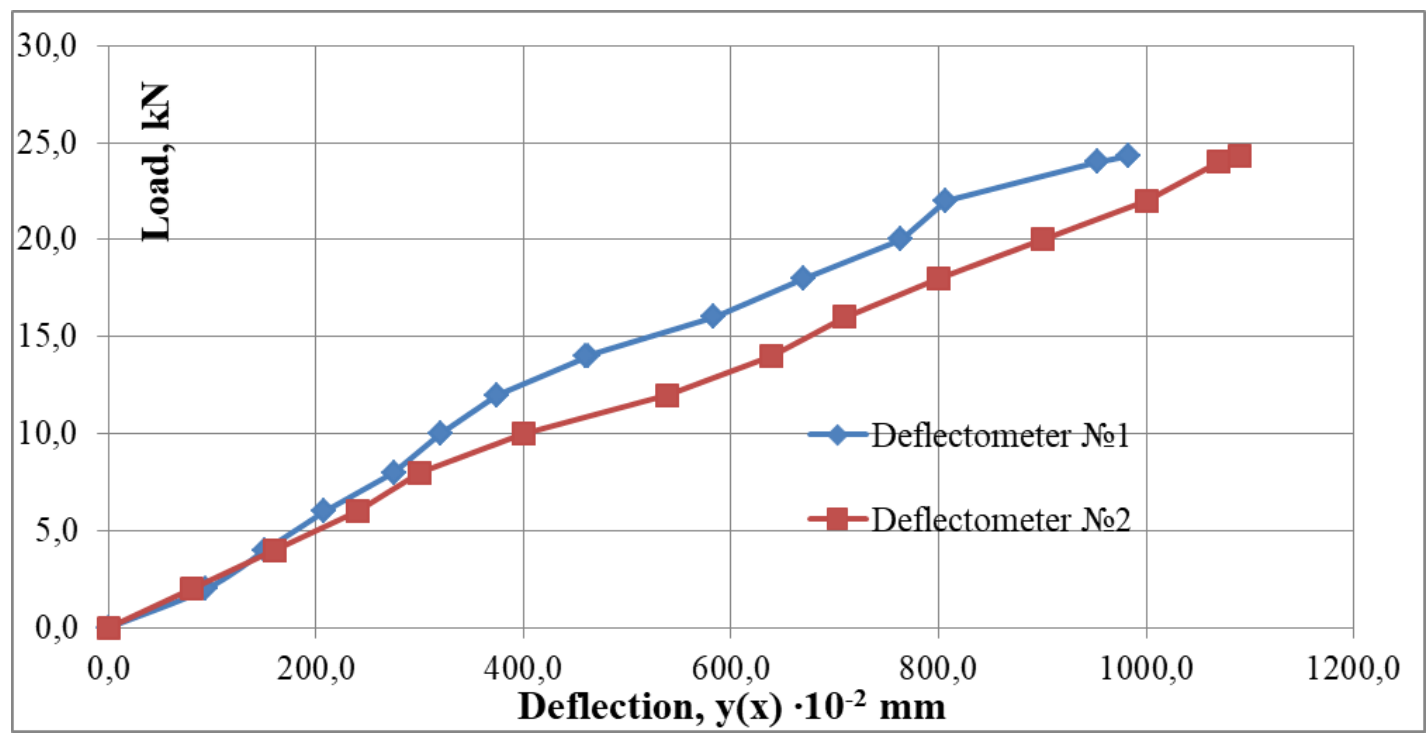

Fig. 10. Deflections in the fiber concrete slab

\section{References}

[1] B.N. Zhemochkyn, A.P. Synytsyn, Praktycheskie metody rascheta fundamentnykh balok $i$ plit na upruhom osnovanyy. Moskva, 1962.

[2] S.D. Semenyuk, R.V. Kumashov, E.A. Ketner, "Nesushchaya i ekspluatatsionnaya sposobnost zhelezobetonnykh plit pokrytiya avtomobilnykh dorog", Nauka ta budivnitstvo, vol. 3. pp, 11-18. 2016.

[3] S.D. Semeniuk, R.V. Kumashov, "Reinforced concrete slabs for paving roads on elastic semi-space", International Journal for Computational Civil and Structural Engineering, vol. 14(2), pp. 149-157, 2018.

[4] V.M. Mitasov, N.V. Statsenko, F.K. Sametov, A.M. Kurbonov, "Eksperimental'nye issledovaniya treshchinostojkosti mnogopustotnyh plit", The Russian Automobile and Highway Industry Journal, vol. 16(3), pp. 366-377, 2019. https://doi.org/10.26518/20717296-2019-3-366-377.

[5] E.N. Badalova, "Zhestkost y treshchynostoikost zhelezobetonnykh mnohopustotnykh plyt perekrytyi, usylennykh armaturoi yz uhlerodnykh volokon", Vestnyk Polotskoho hosudarstvennoho unyversyteta. Seryia F, Stroytelstvo, vol 8, pp. 46-50, 2012. 
[6] P.Chang, Q. F. Yao, A. P. Wang, "Crack Resistance Analyses on RC Composite Floor Slab", Key Engineering Materials, vol. 302-303, pp. 637-643, 2006. doi:10.4028/www.scientific.net/kem.302-303.637.

[7] L. Wang, T. He, Y. Zhou, S. Tang, J. Tan, Z. Liu, J. Su, "The influence of fiber type and length on the cracking resistance, durability and pore structure of face slab concrete", Construction and Building Materials, vol. 282, 122706, 2021. doi:10.1016/j.conbuildmat.2021.12.

[8] J.-Y. Lee, T.-F. Yuan, D.-Y. Yoo, Y.-S. Yoon, "Benefits Of Using Fiber on Impact Resistance of FRC Slabs", MATEC Web of Conferences, vol. 138, 03009, 2017. doi:10.1051/matecconf/20171380300.

[9] G. Tiberti, A. Mudadu, B. Barragan, G. Plizzari, "Shrinkage Cracking of Concrete Slabs-OnGrade: A Numerical Parametric Study", Fibers, vol. 6(3), 64, 2018. doi:10.3390/fib6030064.

[10]M. B. A. Alhasanat, A. N. Al Qadi, "Impact Behavior of High Strength Concrete Slabs with Pozzolana as Coarse Aggregate", American Journal of Applied Sciences, vol. 13(6), pp. 754-761, 2016. doi:10.3844/ajassp.2016.754.761.

[11]DSTU B. V.2.6-137:2010 (HOST 25912.2-91, MOD). Konstruktsii budynkiv i sporud. Plyty zalizobetonni poperedno napruzheni PAH-18 dlia aerodromnoho pokryttia. Konstruktsiia. TOV NTK "Budstandart", 2011.

[12]DSTU B.V.2.6-122:2010. Plyty zalizobetonni z nenapruzhenoiu armaturoiu dlia pokryttia miskykh dorih. K.: Minrehionbud Ukrainy, 2011.

[13] Yu.Y. Zaplatyn, V.N. Sapozhnykov, A.V. Dubov, E.M. Dukhneev, Laboratornyi praktykum po materyalovedenyiu $v$ mashynostroenyy y metalloobrabotke. 4-e yzd., ster. M.: Yzdatelskyi tsentr «Akademyia», 2016.

\title{
ДЕФОРМАТИВНІСТЬ І ТРІЩИНОСТІЙКІСТЬ АЕРОДРОМНИХ ПЛИТ
}

\author{
${ }^{1}$ Сур'янінов М.Г., д.т.н., професор, \\ sng@ogasa.org.ua, ORCID: 0000-0003-2592-5221 \\ ${ }^{1}$ Неутов С.П., к.Т.Н., доцент, \\ neutov.stepan@gmail.com, ORCID: 0000-0002-0132-124X \\ ${ }_{1}^{1}$ Корнеєва I.Б., к.т.н., доцент, \\ korneevairinaborisovna@gmail.com, ORCID: 0000-0002-0104-6938 \\ ${ }^{1}$ Одеська державна академія будівниитва та архітектури \\ вул. Дідріхсона, 4, м. Одеса, 65029, Україна
}

Анотація. Наведено результати експериментальних досліджень деформативності та тріщиностійкості моделей аеродромних плит із залізобетону та сталефібробетону. Випробовано 2 серії плит - три моделі із залізобетону та три моделі з додаванням до бетонної суміші сталевої фібри $1 \%$ від загального обсягу виробу. Навантаження прикладалося невеликими ступенями, на кожному ступені двічі фіксувалися показання приладів, а також, починаючи 3 моменту утворення першої тріщини, вимірювалася ширина розкриття тріщин. Як вимірювальні прилади використовувалися індикатори годинного типу, прогібоміри і мікроскоп МПБ-3. Відповідно до чинних в Україні нормативних документів, розглянуто одну 3 двох можливих схем навантаження - при навантаженні зосередженою силою, прикладеною на консольній частині плити. Моделі плит випробовувалися на спеціально виготовленому стенді, що складався 3 чотирьох опорних стійок, пов'язаних попарно між собою балками. На балки спиралася аеродромна плита. Навантаження прикладалося по ширині плити сходами - по 0,05 від руйнівного, по двох зосереджених вертикальних смуг. Кожна ступінь навантаження закінчувалася п'ятихвилинною витримкою, на початку і в кінці якої знімалися показання на вимірювальних приладах. Деформації на тих же рівнях вимірювали за допомогою індикаторів вартового типу. Процес тріщиноутворення спостерігався за допомогою трубки Брінелля у місцях найбільшого розкриття тріщин.

3 отриманих результатів випливає, що процес тріщиноутворення у фібробетонній плиті починається при більш високих навантаженнях, ніж у залізобетонній. Кінцева та початкова

Bulletin of Odessa State Academy of Civil Engineering and Architecture, 2021, no. 85, page 52-61 
ширина розкриття всіх тріщин у фібробетонній плиті істотно нижча, ніж у залізобетонній. Деформації в плитах із сталефібробетону при додатку навантаження в консольній частині як для стиснених, так і для розтягнутих волокон вище, ніж у залізобетонних плитах. На початкових стадіях застосування навантаження в прогонової частини плит прогини зростають за лінійною залежністю. Криві набувають нелейнійного характеру для аеродромних плит із залізобетону, коли навантаження досягає рівня $10 \div 25 \mathrm{\kappa H}$, для сталефібробетонних плит - $15 \div 30$ кН. У плитах із залізобетону нелінійність починається дещо раніше і виражена чіткіше. Проведені експериментальні дослідження свідчать про те, що дисперсне армування аеродромних плит сталевою фіброю призводить до їхньої вищої тріщиностійкості.

Ключові слова: залізобетон, фібробетон, аеродромна плита, деформативність, тріщиностійкість, експериментальні дослідження.

\title{
ДЕФОРМАТИВНОСТЬ И ТРЕЩИНОСТОЙКОСТЬ АЭРОДРОМНЫХ ПЛИТ
}

\author{
${ }^{1}$ Сурьянинов Н.Г., Д.Т.Н., профессор, \\ sng@ogasa.org.ua, ORCID: 0000-0003-2592-5221 \\ ${ }^{1}$ Неутов С.Ф., к.Т.н., доцент, \\ neutov.stepan@gmail.com, ORCID: 0000-0002-0132-124X \\ ${ }^{1}$ Корнеева И.Б., к.Т.н., доцент, \\ korneevairinaborisovna@gmail.com, ORCID: 0000-0002-0104-6938 \\ ${ }_{1}^{1}$ Одесская государственная академия строительства и архитектуры \\ ул. Дидрихсона, 4, г. Одесса, 65029, Украина
}

Аннотация. Приведены результаты экспериментальных исследований деформативности и трещиностойкости моделей аэродромных плит из железобетона и сталефибробетона. Испытаны 2 серии плит - три модели из железобетона и три модели с добавлением в бетонную смесь стальной фибры $1 \%$ от общего объема изделия. Нагрузка прикладывалась небольшими ступенями, на каждой ступени два раза фиксировались показания приборов, а также, начиная с момента образования первой трещины, измерялась ширина раскрытия трещин. В качестве измерительных приборов использовались индикаторы часового типа и прогибомеры. В соответствии с действующими в Украине нормативными документами, рассмотрена одна из двух возможных схем нагружения - при нагрузке сосредоточенной силой, приложенной на консольной части плиты. Модели плит испытывались на специально изготовленном стенде, состоявшем из четырех опорных стоек, связанных попарно между собой балками. На балки опиралась аэродромная плита. Нагрузка прикладывалась по ширине плиты ступенями - по 0,05 от разрушающей, по двум сосредоточенным вертикальным полосам. Каждая степень нагрузки заканчивалась пятиминутной выдержкой, в начале и конце которой снимались показания на измерительных приборах. Деформации на тех же уровнях измеряли с помощью индикаторов часового типа. Процесс трещинообразования наблюдался с помощью трубки Бринелля в местах наибольшего раскрытия трещин.

Из полученных результатов следует, что процесс трещинообразования в фибробетонной плите начинается при более высоких нагрузках, чем в железобетонной. Конечная и начальная ширина раскрытия всех трещин в фибробетонной плите существенно ниже, чем в железобетонной. Деформации в плитах из сталефибробетона при приложении нагрузки в консольной части, как для сжатых, так и для растянутых волокон выше, чем в железобетонных плитах. На начальных стадиях приложения нагрузки в пролетной части плит прогибы возрастают по линейной зависимости. Кривые получают нелейнейный характер для аэродромных плит из железобетона, когда нагрузка достигает уровня $10 \div 25 \mathrm{\kappa H}$, для

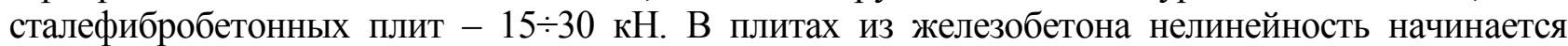
несколько раньше и выражена более четко. Проведенные экспериментальные исследования свидетельствуют о том, что дисперсное армирование аэродромных плит стальной фиброй приводит к их более высокой трещиностойкости.

Ключевые слова: железобетон, фибробетон, аэродромная плита, деформативность, трещиностойкость, экспериментальные исследования.

Стаття надійшла до редакції 28.11.2021

Bulletin of Odessa State Academy of Civil Engineering and Architecture, 2021, no. 85, page 52-61 